\title{
Cell cycle dependent expression of toxicity by the ichthyotoxic prymnesiophyte Chrysochromulina polylepis
}

\author{
Erik Eschbach ${ }^{1}$, Uwe Johnn ${ }^{2, *}$, Marcus Reckermann ${ }^{3}$, Allan D. Cembella ${ }^{2}$, \\ Bente Edvardsen ${ }^{4}$, Linda K. Medlin ${ }^{2}$ \\ ${ }^{1}$ Lohmann Animal Health GmbH \& Co. KG, Heinz-Lohmann-Strasse 4, 27472 Cuxhaven, Germany \\ ${ }^{2}$ Alfred-Wegener-Institut für Polar- und Meeresforschung, Am Handelshafen 12, 27570 Bremerhaven, Germany \\ ${ }^{3}$ Coastal Research Laboratory, Research and Technology Centre of Kiel University, Otto-Hahn-Platz 3, 24098 Kiel, Germany \\ ${ }^{4}$ Department of Biology, University of Oslo, PO Box, 1069 Blindern, 0316 Oslo, Norway
}

\begin{abstract}
The coupling of toxicity expression with cell-cycle phases was studied in the toxic marine prymnesiophyte Chrysochromulina polylepis Manton \& Parke, Clone B1511. Cell synchronisation of cultures in exponential or early stationary growth phases under nutrient-replete conditions was achieved by manipulation of the photoperiod. Chlorophyll $a(\mathrm{chl} a)$ and cell number increased in a stepwise manner, but were asynchronous, with chl $a$ increasing during the light period and cell number increasing during the dark period. In the course of the light period, nearly all cells clustered in the G1 (Gap 1) phase, which lasted for about $20 \mathrm{~h}$. DNA synthesis (S phase) occurred mainly in the dark during a discrete period (about $4 \mathrm{~h}$ ) and G2 (Gap 2) and mitosis (M) were always completed before the end of the dark period. Toxicity expression, measured by the erythrocyte lysis assay (ELA), exhibited a dramatic drop in $\mathrm{LC}_{50}$ values (increase in toxicity) during the light period, although this effect was less pronounced after the first 2 generations of cell division when the cultures had entered the stationary phase. Similarly, haemolytic activity per unit cell volume decreased by a factor of 3 to 4 during the dark period over the first $48 \mathrm{~h}$, but became irregular towards the end of the experiment. In this study, the light-dependent effect on toxicity and relationship to discrete phases of the cell cycle are demonstrated for the first time in a prymnesiophyte.
\end{abstract}

KEY WORDS: Cell cycle $\cdot$ Ichthyotoxins $\cdot$ Phytoflagellates $\cdot$ Prymnesiophytes $\cdot$ Chrysochromulina polylepis

\section{INTRODUCTION}

Phytoflagellates are particularly well represented among the numerous toxigenic microalgae responsible for harmful algal blooms in coastal marine and brackish waters throughout the world (Hallegraeff 1993). Most of these blooms are attributed to dinoflagellates, but other flagellate groups, including raphidophytes, pelagophytes and prymnesiophytes are often implicated, particularly in incidents of fish kills and other mass faunal mortalities. For example, in May 1988, the marine flagellate Chrysochromulina polylepis Manton et Parke (Prymnesiophyceae) caused a devastating toxic bloom, resulting in extensive fish kills in the Kattegat and Skagerrak, which connects the Baltic Sea with the North Sea (Dahl et al. 1989). The bloom covered an area of approximately $7.5 \times 10^{4} \mathrm{~km}^{2}$ and reached concentrations of $10 \times 10^{7}$ cells $\mathrm{l}^{-1}$ during the peak of the bloom (Dahl et al. 1989, Granéli et al. 1993). In later stages, the bloom was essentially monospecific, with $C$. polylepis as the dominant microalgal species. The bloom exhibited strong toxicity to various marine organisms, leading to severe ecological damage to wild biota and to high economic losses at fish farms along the Norwegian and Swedish coasts (Rosenberg et al. 1988, Nielsen et al. 1990, Skjoldal \& Dundas 1991). Subsequently, Chrysochromulina blooms (not only of C. polylepis) have been repeatedly observed, some of which have caused fish mortalities (Tangen \& Brieby 1988, Tangen 1989, Edvardsen \& 
Paasche 1998 [review], Johnsen et al. 1999). The definitive causes of these blooms remain unknown, but in addition to meteorological, hydrographical and chemical conditions that promote growth and toxin production in Chrysochromulina spp., adverse effects on planktonic grazers may also have played a role in bloom development (Nielsen et al. 1990, John et al. 2002).

The chemical characterisation of Chrysochromulina polylepis toxin(s) is still lacking. The mode of action of these toxins is apparently non-selective, causing interference mainly with membrane functions, and thus organisms ranging from protozoans to fish are known to be affected (Skjoldal \& Dundas 1991, Gjøsæter et al. 2000). Yasumoto et al. (1990) described the toxins as glucolipids and/or fatty acids, but John et al. (2002) showed that a toxic and an apparently non-toxic clone of C. polylepis exhibited the same lipid and fatty acid composition.

Curiously, prior to the major ichthytoxic event in Scandinavia, Chrysochromulina polylepis had been considered to be non-toxic to fish (Manton \& Parke 1962) and only slightly toxic to a bryozoan, Electra pilosa (Jebram 1980). Toxicity of C. polylepis was demonstrated to be highly variable within and among strains of this species (review by Edvardsen \& Paasche 1998). Little is known of the factors triggering toxicity, but unbalanced nutrient conditions such as high levels of ambient nitrogen $(\mathrm{N})$ and limiting amounts of phosphorus (P)-conditions that exist in many coastal regions due to human activity - seem to play an especially important role in the manifestation of $C$. polylepis toxicity (Edvardsen et al. 1990, 1996, Edvardsen 1993). Laboratory experiments have confirmed that toxicity of C. polylepis is strongly dependent on the $\mathrm{pH}$ of the culture medium (Schmidt \& Hansen 2001) and the cellular N:P ratio (Johansson \& Granéli 1999).

In order to define the mechanisms involved in the expression of toxicity in Chrysochromulina polylepis, it is necessary to identify the exogenous and endogenous factors that induce and regulate toxin production at the cellular level. This can best be achieved by cell-cycle analysis of synchronised or at least highly phased cultures. The entrainment of microalgal cells towards synchronous division is most often attempted by exogenous control via regulation of light and/or nutrient concentration and supply rate.

Circadian rhythms among the phytoflagellates are well known to be associated with both nutrient assimilation and light utilisation. Among dinoflagellates, diel vertical migration has been shown to be nutrientmediated, although not obviously linked to toxin biosynthesis (MacIntyre et al. 1997). Light plays a critical role in regulating rhythmic physiological processes, e.g. cell division, nutrient assimilation, biolumines- cence, toxin production, the onset of sexual reproduction, vertical migration, etc. (Taroncher-Oldenburg et al. 1997). The cell division cycles of most phytoflagellate species are therefore phased or synchronised to photocycles (Chisholm 1981, Chisholm et al. 1984, Gerath \& Chisholm 1989). For experimental purposes, manipulation of the light regime (as opposed to nutrients, temperature or use of metabolic inhibitors) allows virtually instantaneous alteration in magnitude and frequency of the exogenous regulator.

The eukaryotic cell cycle is generally divided into 4 phases: M (mitosis), G1 (Gap 1), S (DNA synthesis), and G2 (Gap 2). Although early work on the unusual nuclei of certain phytoflagellates, particularly the 'mesokaryotic' dinoflagellates (summarised by Rizzo 1987), led to suspicions that this pattern may not be consistently maintained, Chisholm (1981) showed that this cell-cycle sequence is universal for all eukaryotic microalgae. The cell cycle is initiated with mitotic division ( $\mathrm{M}$ phase), followed by G1 phase, where the cells are metabolically very active, and S phase when DNA synthesis occurs. The G2 phase, where the cell contains 2 copies of nuclear DNA, terminates at mitotic division, and ultimately cytokinesis occurs. Among prymnesiophytes, such as Chrysochromulina polylepis, this asexual mitotic cycle continues with successive cycles of cell division, and sexuality is rarely, if ever, observed. As in dinoflagellates (except Noctiluca scintillans), the vegetative, authentic cell type of $C$. polylepis (e.g. Clone B1511) is haploid (n), with the diploid stage restricted to cell-cycle events subsequent to the $\mathrm{S}$ phase. Vegetative, alternate cells of $C$. polylepis (e.g. Clone B11), however, may be either haploid or diploid (Edvardsen \& Vaulot 1996).

The aim of the present work was to investigate whether or not the expression of toxicity in Chrysochromulina polylepis is coupled to a defined period within the cell cycle, as previously shown for dinoflagellates (Taroncher-Oldenburg et al. 1997, Pan et al. 1999).

\section{MATERIALS AND METHODS}

Synchronisation conditions and sampling procedure. Experiments were conducted with a toxic, haploid clone (B1511) of Chrysochromulina polylepis. Clone B11, which did not express toxicity according to various bioassays, was used as a control in the erythrocyte lysis assay (ELA). Both clones were isolated by Bente Edvardsen, University of Oslo, and originate from the Oslofjord, Norway $\left(59^{\circ} 00^{\prime} \mathrm{N}, 10^{\circ} 45^{\prime} \mathrm{E}\right)$. Each clone represents 1 of the 2 morphologically different cell types of C. polylepis, previously described in detail (Paasche et al. 1990, Edvardsen \& Paasche 1992, 
Edvardsen \& Vaulot 1996). C. polylepis was grown in enriched seawater medium IMR 1/2 (Eppley et al. 1967) supplemented with $10 \mathrm{nM}$ selenite in batch cultures at $15^{\circ} \mathrm{C}$ under white fluorescent light with a photon flux density of $45 \mu \mathrm{mol} \mathrm{s} \mathrm{s}^{-1} \mathrm{~m}^{-2}$, applied on a 14:10 h light:dark regime. For synchronisation, unialgal cultures in exponential growth phase were inoculated with $1 \times 10^{4}$ cells ml $\mathrm{m}^{-1}$ in sequence into $0.05,0.5$, 1,5 and finally into $10 \mathrm{l}$ flasks to reach a final concentration of $1.5 \times 10^{5}$ cells $\mathrm{ml}^{-1}$ before each transfer. We gently bubbled 5 and 101 cultures with sterile-filtered air to provide $\mathrm{CO}_{2}$ and to achieve homogenous cell distribution. Sampling was done from 3 parallel cultures during exponential growth throughout a culture period of $72 \mathrm{~h}$ at $2 \mathrm{~h}$ intervals, starting at a cell concentration of about $4 \times 10^{4}$ cells $\mathrm{ml}^{-1}$. Samples were collected from 101 cultures via a silicone-rubber tube with an inner diameter of $3 \mathrm{~mm}$ by gently applying a vacuum created by drawing on a $50 \mathrm{ml}$ syringe. Samples were immediately stored on ice and, after determination of the cell numbers, processed according to their respective analytical procedure. During the dark period, samples were collected in darkness under a red darkroom safety light to avoid disturbance of synchronous growth and algal metabolism. The degree of synchronisation of C. polylepis cultures was calculated by the algorithm of Engelberg (1961).

Determination of cell concentration and size. Samples $(2 \mathrm{ml})$ were diluted in $18 \mathrm{ml}$ of sterile seawater pre-cooled to $15^{\circ} \mathrm{C}$ to determine cell concentration. Cell numbers were counted with a Multisizer II particle counter (Coulter Electronics) equipped with a $100 \mu \mathrm{m}$ aperture. Cells were counted within a size window of 5 to $12 \mu \mathrm{m}$, which excluded background particles present in the seawater. Average cell size with standard deviation (SD) was calculated with Coulter Multisizer Software. Calculation of specific growth rate $\left(\mu, \mathrm{d}^{-1}\right)$ was performed using the formula:

$$
\mu=\left[\ln \left(C_{1}\right)-\ln \left(C_{0}\right)\right] / 1
$$

where $C_{1}$ is the cell concentration at Time 1 and $C_{0}$ is the cell concentration at Time 0 .

Growth rate $\left(k\right.$, divisions $\left.\mathrm{d}^{-1}\right)$ was calculated as:

$$
k=\mu / \ln (2)
$$

Chlorophyll determination. Samples for chlorophyll a (chl a) determination were prepared by filtering $5 \mathrm{ml}$ of algal culture in triplicate onto glass microfibre filters GF/F (Whatman) followed by extraction with $10 \mathrm{ml}$ $90 \%$ acetone at $-20^{\circ} \mathrm{C}$. Chl a concentrations were measured by fluorometry (Gamma Analysen Technik, Type 10AK) using an excitation wavelength of $435 \mathrm{~nm}$ and emission fluorescence at $670 \mathrm{~nm}$. Fluorescence of other pigments was subtracted by measuring the samples again after acidification with $1 \mathrm{~N} \mathrm{HCl}$. Chl a con- centration (ng ml$^{-1}$ ) was determined using the formula (Arar \& Collins 1992) as follows:

$$
\operatorname{chl} a=F_{\mathrm{m}} /\left(F_{\mathrm{m}}-1\right) \times\left(F_{0}-F_{\mathrm{a}}\right) \times K_{\mathrm{x}} \times\left(\mathrm{Vol}_{\mathrm{Ex}} / \mathrm{Vol}_{\mathrm{S}}\right)
$$

where $F_{\mathrm{m}}$ is the acidification coefficient of chl a standard $(=2.18), F_{0}$ is the relative fluorescence before acidification, $F_{\mathrm{a}}$ is the relative fluorescence after acidification, $K_{\mathrm{x}}$ is the calibration factor $(=2.48), \mathrm{Vol}_{\mathrm{Ex}}$ is the extract volume $(=10 \mathrm{ml})$, and $\mathrm{Vol}_{\mathrm{S}}$ is the sample volume $(=5 \mathrm{ml})$.

Cell-cycle analysis. Samples $(20 \mathrm{ml})$ of Chrysochromulina polylepis culture were fixed with $0.25 \%$ glutaraldehyde, stained with $5 \mu \mathrm{M}$ SytoxGreen (Molecular Probes) and subsequently analysed for relative DNA content using a FACS Vantage flow cytometer (BectonDickinson) equipped with an Innova Enterprise II 621 laser, as previously described (Eschbach et al. 2001a). In brief, at least $1 \times 10^{4}$ cells were analysed per sample at a pressure of 1 psi. Dot-plots and histograms were created with the WinMDI 2.8 software (Joseph Trotter, Scripps Research Institute, La Jolla, CA, USA). Cellcycle analysis was achieved with the Multicycle software (Phoenix Flow Systems). The number of cells in a certain cell-cycle phase was expressed as the percentage of the total cell number in the sample. The duration of single cell-cycle phases was determined based on the algorithm developed by Beck (1978) for synchronised cell cultures. The duration of G1, S and $\mathrm{G} 2+\mathrm{M}$ phases was calculated for 2 consecutive complete cell cycles of C. polylepis.

Toxicity determination. The toxicity of Chrysochromulina polylepis was determined with an improved version of the ELA, as previously described (Eschbach et al. 2001b). This assay is based on the lysis of carp erythrocytes resulting from membrane perturbation activity of $C$. polylepis toxin(s), and the subsequent photometric measurement of released cellular contents at $414 \mathrm{~nm}$. We performed 2 types of toxicity measurements: (1) $4.8 \times 10^{6}$ cells were sampled every $2 \mathrm{~h}$ throughout the $72 \mathrm{~h}$ sampling period to measure haemolytic activity; (2) $6.4 \times 10^{6}$ cells were sampled $8 \mathrm{~h}$ after the start of the light period (since preliminary experiments had indicated high toxicity at this point), every day throughout the sampling period (i.e. after 24 , 48 and $72 \mathrm{~h}$ ), to measure toxicity kinetics. Samples were centrifuged for $15 \mathrm{~min}$ at $3200 \times g$ at $4^{\circ} \mathrm{C}$ in $15 \mathrm{ml}$ tubes to yield cell pellets of $0.4,0.8$ or $1.6 \times 10^{6}$ cells per tube, depending on the cell concentration in the culture at the time of sampling. Pellets were frozen immediately and stored at $-20^{\circ} \mathrm{C}$ until analysis.

The kinetic analysis was done in order to determine the optimal incubation time $\left(I T_{\text {opt }}\right)$ in the ELA, which varied in preceding experiments. Preliminary work showed that toxicity of synchronised Chrysochromulina polylepis cultures was high at $8 \mathrm{~h}$ after the start 
of the light period; therefore, this sampling point was selected for toxicity kinetic measurements (E. Eschbach unpubl. data). Different levels of toxicity were simulated by exposing the erythrocytes to dilutions of algal extracts corresponding to $1,2,3,4$ and $5 \times$ $10^{5}$ cells $\mathrm{ml}^{-1}$ (= final concentration in the ELA). Lytic activity was determined at $4 \mathrm{~h}$ intervals for $24 \mathrm{~h}$. The percentage erythrocyte lysis (haemolysis) was then plotted against incubation time to yield a series of curves showing the degree of haemolysis as a function of incubation time and concentration of algal extract (Fig. 1). The $I T_{\text {opt }}$ were chosen where the differences in haemolytic activity among the algal extract dilutions showed the greatest differences, allowing for an optimal detection of difference in toxicity.

Haemolytic measurements with the ELA were performed in triplicate according to Eschbach et al. (2001b). Haemolytic activity was calculated as the percentage of lysis of carp erythrocytes, by comparing absorbance mediated by the lytic activity of algal extracts with absorbance obtained from completely lysed erythrocytes, defined as $100 \%$ lysis.

To determine the cell concentration that resulted in $50 \%$ erythrocyte lysis after $16 \mathrm{~h}$ exposure ( $\mathrm{LC}_{50} 16 \mathrm{~h}$ values), logarithmically transformed algal cell concentrations were separately plotted against erythrocyte lyses for each sampling point. $\mathrm{LC}_{50}$ was subsequently calculated from the linear part of the resulting curves using linear regression analysis and plotted against time. Haemolytic activity was also calculated relative to the cell volume at each respective sampling point, to take into account the changing cell volume during cell growth. The cell volume was calculated from the cell-

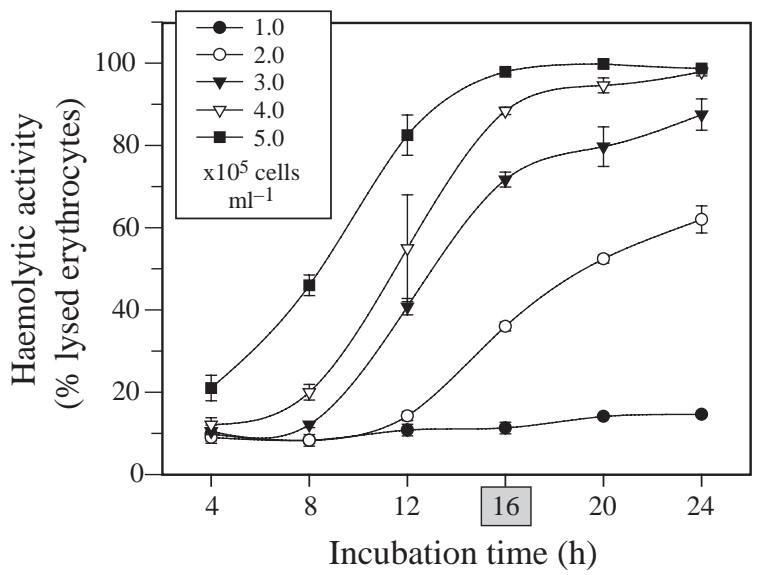

Fig. 1. Chrysochromulina polylepis. Toxicity kinetics for determination of optimal incubation time $\left(I T_{\mathrm{opt}}\right)$ of algal extracts with erythrocytes in erythrocyte lysis assay. Different toxicity of algal extracts was simulated in these measurements by exposing erythrocytes to dilutions of algal extracts corresponding to $1,2,3,4$ and $5 \times 10^{5}$ cells ml $^{-1}$. Haemolytic activity of the diluted extracts was measured at $4 \mathrm{~h}$ intervals for $24 \mathrm{~h}$ size measurements, assuming the algal cells to be spherical. For these calculations, the haemolytic activity of $5 \times 10^{5}$ algal cells $\mathrm{ml}^{-1}$ (final concentration) was divided by the cell volume $\left(4 / 3 \pi r^{3}\right.$, where $r=$ cell radius $)$.

\section{RESULTS}

\section{Synchronous growth kinetics and chl a synthesis}

All results described herein originate from 3 independently sampled $10 \mathrm{l}$ batch cultures of Chrysochromulina polylepis Clone B1511 growing under identical synchronising conditions. Growth of C. polylepis Clone B1511 in batch culture under synchronising conditions is depicted in Fig. 2A. Sampling was initiated at a cell density of approximately $4 \times 10^{4}$ cells $\mathrm{ml}^{-1}$ and was continued for a $72 \mathrm{~h}$ period, indicated by the arrow in Fig. 3. Given an inoculum of $1 \times 10^{4}$ cells ml-1 on Day 1 , the cells reached early exponential growth phase within the first day in the $10 \mathrm{l}$ cultures. A maximum cell density of about $3.5 \times 10^{5}$ cells $\mathrm{ml}^{-1}$ was achieved within $10 \mathrm{~d}$ after the first inoculation.

Chrysochromulina polylepis cultures showed a stepwise increase in both cell number and cellular chl a concentrations during the $72 \mathrm{~h}$ sampling period (Fig. 2A). This is because of the experimental culture procedure, which produced $58 \%$ synchronisation of the algal population during the first $24 \mathrm{~h}$ of the sampling period. After this initial period, synchronisation increased in successive steps of approximately $5 \%$, yielding 63 and $68 \%$ synchronisation after 48 and $72 \mathrm{~h}$, respectively.

Increases in chl $a$ and cell number were shifted in time, with chl a increasing during the light period and cell number increasing during the dark period. Increases in cellular chl a began after the switch from dark to light and continued throughout the entire light period. Conversely, a decrease in chl a content occurred after the light to dark switch and continued throughout the entire dark period due to reduction of cell content during cell division (Fig. 2B). During the first $24 \mathrm{~h}$ of the sampling period, an increase in cell number was initiated and then terminated within the same dark period, yet through the next two $24 \mathrm{~h}$ periods, this increase in cell number extended $2 \mathrm{~h}$ and finally $4 \mathrm{~h}$ into the light period (Fig. 2A).

The growth rate of Chrysochromulina polylepis decreased over time from 0.82 to $0.65-0.61$ divisions (div.) $\mathrm{d}^{-1}$ during the $3 \mathrm{~d}$ experiment. Cell size (equivalent spherical diameter) varied periodically during the $72 \mathrm{~h}$ sampling period from a maximum of $8.3 \mu \mathrm{m}$ to a minimum of $6.7 \mu \mathrm{m}$ (Fig. 2D). Towards the end of the sampling period, cells became smaller, as indicated by a maximum cell size of only $7.5 \mu \mathrm{m}$ on Day 3 of the sampling period. 

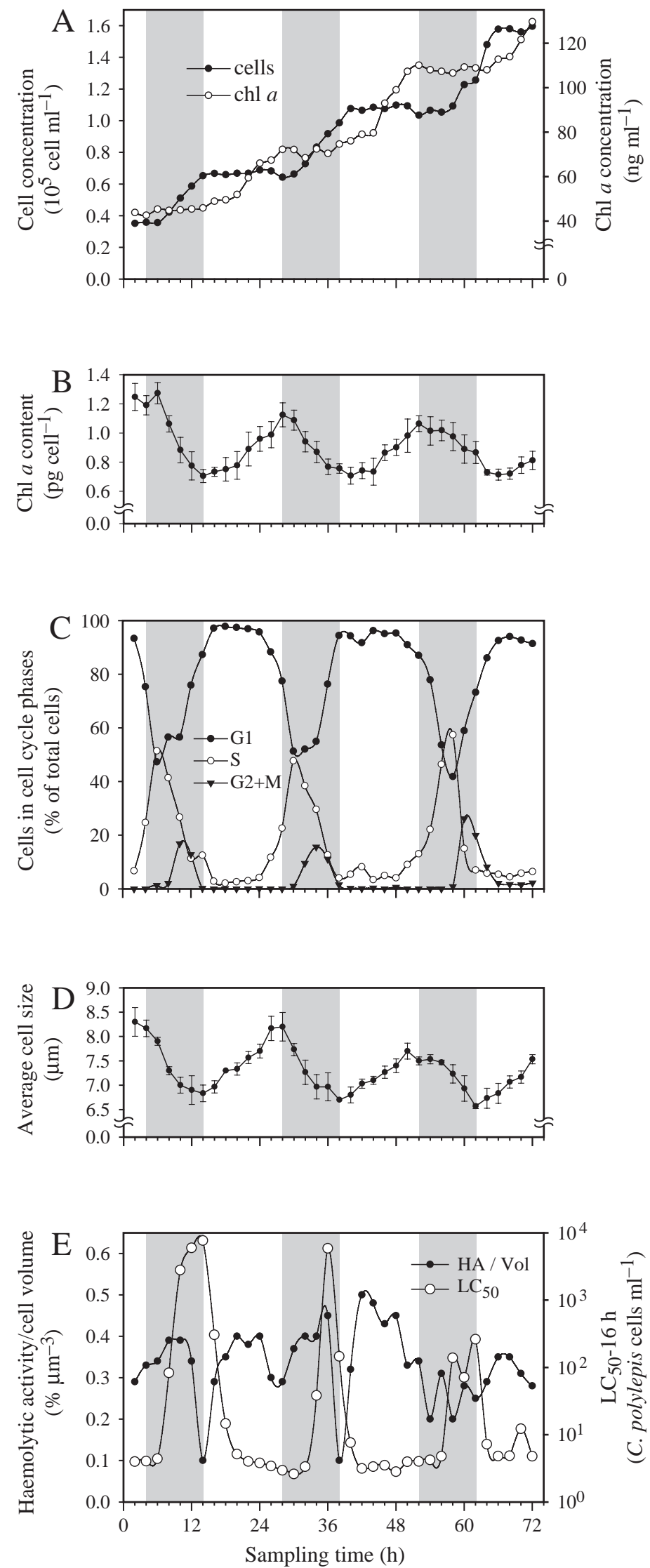

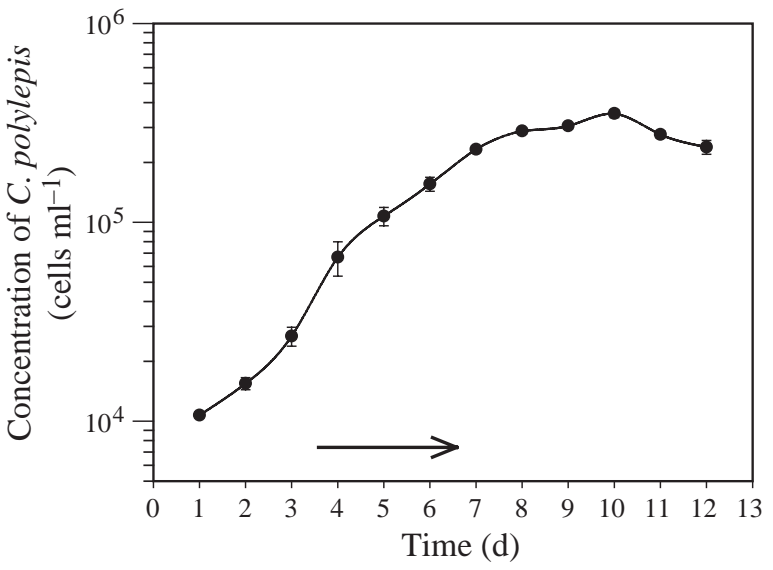

Fig. 3. Chrysochromulina polylepis Clone B1511. Mean $( \pm \mathrm{SD}$; $\mathrm{n}=3$ ) concentration over a $2 \mathrm{wk}$ period in synchronised batch cultures. Arrow indicates sampling period of $72 \mathrm{~h}$

\section{Cell-cycle analysis}

Flow cytometry determination of the relative DNA content of Chrysochromulina polylepis revealed successive cell-cycle phases typical for eukaryotic cells (Fig. 2C). Single distinct peaks for the G1, S and $\mathrm{G} 2+\mathrm{M}$ phases were obtained for each cell cycle (G2 and $M$ phases cannot be distinguished by flow cytometry because cells in these respective phases contain the same amount of DNA).

Our results (Fig. 2C) show that Chrysochromulina polylepis proceeds, as expected, through the typical phases of a eukaryotic cell cycle, consisting of mitosis ( $M$ phase) followed by the metabolically active G1 phase, the S phase of DNA synthesis and the S and M phases separating the G2 phase. As summarised in Table 1 and illustrated in Fig. 2C. The $\mathrm{S}$ phase in C. polylepis takes place during a discrete period of approximately $4 \mathrm{~h}$ following G1 phase. The G2 and M phases occur within 1 to $2 \mathrm{~h}$ after the $\mathrm{S}$ phase.

DNA synthesis (S phase) always began $2 \mathrm{~h}$ before and was completed by the end of the dark period (Fig. 2C). During the first $48 \mathrm{~h}$ of the sampling period, a peak of DNA synthesis appeared after $2 \mathrm{~h}$ in the

Fig. 2. Chrysochromulina polylepis Clone B1511. Data from 3 synchronised batch cultures during the $72 \mathrm{~h}$ sampling period. (A) Algal cell concentration and chlorophyll a (chl a) concentration as a function of time; (B) chl a content per cell (derived from data in A); (C) percentage of cells in G1, S and G2+M phases of cell cycle; (D) average cell size (equivalent spherical diameters); (E) toxicity of algal cells expressed as haemolytic activity relative to cell volume (HA/Vol) and as cell concentration required for $50 \%$ erythrocyte lysis $\left(\mathrm{LC}_{50}\right)$. Data points are mean $( \pm \mathrm{SD})$ of 3 independent measurements; error bars omitted from graphs with more than 1 curve $(A, C, E)$ for clarity. Shaded areas: $10 \mathrm{~h}$ dark periods; G1: Gap 1; S: DNA synthesis; G2+M: Gap 2+mitosis phases 
Table 1. Chrysochromulina polylepis Clone B1511. Duration of cell-cycle phases in 2 consecutive cycles, calculated according to Beck (1978) using time intervals from 6 to $48 \mathrm{~h}$ and from 30 to $72 \mathrm{~h}$, respectively. Results are expressed in absolute numbers (h) and as percent (\%) of total duration (Total) of a complete cell cycle. Means \pm SD are calculated from 3 independent 101 batch cultures. G1: Gap 1; S: DNA synthesis; G2 + M: Gap 2 and mitosis

\begin{tabular}{|lrcrc|}
\hline \multirow{2}{*}{ Phase } & \multicolumn{2}{c}{$\begin{array}{r}\text { 1st complete cycle } \\
\text { (6 to } 48 \mathrm{~h})\end{array}$} & \multicolumn{2}{c|}{ 2nd complete cycle } \\
& \multicolumn{1}{c}{$\mathrm{h}$} & \multicolumn{2}{c}{$\%$} & \multicolumn{2}{c|}{$\mathrm{h}$} & $\%$ \\
\hline $\mathrm{G} 1$ & $19.6 \pm 0.3$ & $78.7 \pm 1.1$ & $22.0 \pm 0.6$ & $79.3 \pm 2.2$ \\
$\mathrm{~S}$ & $4.3 \pm 0.9$ & $17.1 \pm 3.5$ & $4.1 \pm 0.1$ & $14.8 \pm 0.5$ \\
$\mathrm{G} 2+\mathrm{M}$ & $1.0 \pm 0.7$ & $4.1 \pm 2.6$ & $1.6 \pm 0.8$ & $5.8 \pm 2.9$ \\
Total & $24.8 \pm 1.9$ & 100 & $27.8 \pm 1.6$ & 100 \\
\hline
\end{tabular}

dark. The third S phase peak was shifted by $4 \mathrm{~h}$ within the third dark period. Cell division $(\mathrm{G} 2+\mathrm{M})$ started and was completed during the dark periods of the first $48 \mathrm{~h}$ of the sampling period. By the end of the sampling period, cell division extended into the light period and the delay between the $\mathrm{S}$ and $\mathrm{G} 2+\mathrm{M}$ peaks was reduced to $2 \mathrm{~h}$. An increase in the number of cells in the $\mathrm{S}$ and $\mathrm{G} 2+\mathrm{M}$ phases was always synchronous with a decrease in the number of cells in the G1 phase. During the first $48 \mathrm{~h}$ of the sampling period, nearly all cells clustered in G1 by the end of the dark period.

The duration of the cell-cycle phases, determined according to Beck (1978), was calculated during the 6 to $48 \mathrm{~h}$ interval shown in Fig. $2 \mathrm{C}$ for the first cycle, and the 30 to $72 \mathrm{~h}$ interval for the second complete cycle. The G1 phase occupied most of the cell cycle of Chrysochromulina polylepis, with $19.6 \pm 0.3$ and $22.0 \pm$ $0.6 \mathrm{~h}(\mathrm{n}=3)$ duration for the first and the second complete cycle, respectively (Table 1 ). The mean duration of the S phase was $4.3 \pm 0.9$ and $4.1 \pm 0.1 \mathrm{~h}(\mathrm{n}=3)$, whereas the $\mathrm{G} 2+\mathrm{M}$ phase lasted $1.0 \pm 0.7$ and $1.6 \pm$ $0.8 \mathrm{~h}(\mathrm{n}=3)$ in successive cycles. Total cell-cycle duration increased slightly from $24.8 \pm 1.9$ to $27.8 \pm 1.6 \mathrm{~h}$ $(\mathrm{n}=3)$ during the $72 \mathrm{~h}$ sampling period.

\section{Toxin assays}

Calculations of lytic activity from the ELA, based on percentage haemolysis at different time points, showed that $16 \mathrm{~h}$ was the optimal incubation time for sensitive high-resolution measurements with the ELA (Fig. 1). Extracts of the ichthyotoxic Strain B1511 and the non-toxic B11 clone of Chrysochromulina polylepis revealed different haemolytic capacities, but the differences were a matter of degree, not absolute (Fig. 4). Specifically, B1511 extracts yielded nearly 100\% erythrocyte lysis after an incubation time of $16 \mathrm{~h}$, yet B11 extracts also exhibited about $40 \%$ lysis for this period.

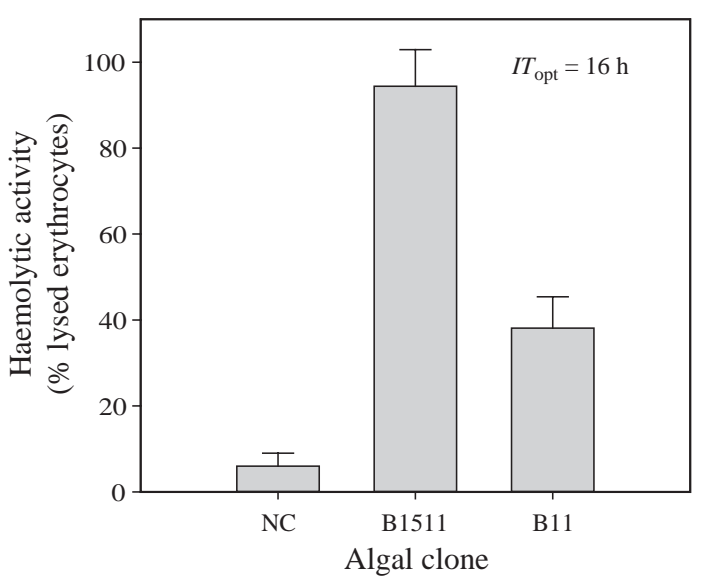

Fig. 4. Chrysochromulina polylepis. Comparison of haemolytic activity of extracts of ichthyotoxic Clone B1511 versus almost non-toxic Clone B11. Extracts of $5 \times 10^{5} \mathrm{cells} \mathrm{ml}^{-1}$ of each clone were incubated for $16 \mathrm{~h}$ (optimal incubation time, $\left.I T_{\text {opt }}\right)$. Histograms represent mean (+SD) of 6 independent measurements. NC: negative control

As depicted in Fig. 2E, the cellular lytic capacity of Strain B1511, expressed as $\mathrm{LC}_{50}$ and as haemolytic activity per unit algal cell volume, varied periodically throughout the sampling period. Haemolytic activity dropped during the initial dark periods, resulting in an increase of more than 3 orders of magnitude in the number of algal cells required for $50 \%$ erythrocyte lysis during the first $48 \mathrm{~h}$. In the third dark period, the phenomenon was less pronounced.

The haemolytic activity of algal cells as expressed per unit algal cell volume varied over the sampling period in a similar fashion. During the first $48 \mathrm{~h}$, lytic activity per unit cell volume decreased by a factor of 3 to 4 during the dark periods and became irregular towards the end of the experiment.

\section{DISCUSSION}

\section{Synchronisation and growth}

Analyses of synchronised cultures are useful to enhance the signal from induced toxin production and provide insights into regulation, because the induction of a given biosynthetic pathway is phased to the cell division cycle and essentially occurs at the same time point for all cells in a culture. Establishment of synchronous growth conditions was therefore essential for analysis of toxin production in relation to the cell cycle of Chrysochromulina polylepis. A high degree of synchronisation was necessary to allow clear identification of cell-cycle stages in following temporal changes in toxin synthesis throughout the 3 d sampling period. 
Alternative methods have been employed to achieve synchronisation of microalgal cultures. The blockrelease approach involves use of metabolic inhibitors (van Dolah et al. 1998, Ng et al. 1999) or light and/or nutrient deprivation techniques (Olson \& Chisholm 1986, Vaulot et al. 1986, Taroncher-Oldenburg et al. 1997, Pan et al. 1999). The block-release method is based on the fact that under unfavourable growth conditions cells may be arrested in the G1 phase of the cell cycle (then termed G0 phase). In theory, and often in practice, the initial block of the cell cycle yields cells completely arrested in G0; after release, cells will proceed through the rest of the cell-cycle stages as a homogenous population (Pardee et al. 1978).

For Chrysochromulina polylepis experiments, it was possible to entrain or phase the cell-division cycle to near synchronicity by means of a repeated photoperiod. Although not always possible to apply, this method has clear advantages over the block-release method for studying periodic responses since no sudden stress is necessary to induce synchronicity. At least in the case of metabolic inhibitors, there is also less potential for introducing artefacts into the cell cycle. Partial synchronisation induced by light:dark cycles has been obtained for the haptophytes Phaeocystis spp. (Vaulot et al. 1994, Jacobsen 2002), Prymnesium parvum (Chisholm 1981, Larsen \& Edvardsen 1998) and C. polylepis (Edvardsen \& Vaulot 1996), and has also been reported for many other microalgae including chlorophytes of the genera Chlorella, Scenedesmus, and Chlamydomonas and the euglenophyte Euglena (Wanka et al. 1972, Ober 1975, Carré \& Edmunds 1993, Lemaire et al. 1999). In practice, the induction of synchronous (as opposed to merely phased) cell division by manipulation of the photoperiod is only possible when the length of the celldivision cycle closely approximates the length of the photoperiod ( 1 div. $\mathrm{d}^{-1}$ ).

High levels of synchronisation in Chrysochromulina polylepis were obtained by the sequential inoculation of increasingly larger culture volumes of cells from early exponential growth phase entrained to a 14:10 h light:dark regime. A favourable factor in these experiments was that high growth rates may be achieved (although not necessarily sustained) by C. polylepis populations. Under routine culture conditions, growth rates of ca. 0.5 div. $\mathrm{d}^{-1}$ (data not shown) were obtained with this strain of C. polylepis, but under exceptional growth conditions growth rates as high as 1.3 div. $\mathrm{d}^{-1}$ have been achieved with this species (Edvardsen \& Paasche 1992, Throndsen et al. 1995). In our toxicity expression experiments, C. polylepis reached maximum growth rates of 0.82 div. $\mathrm{d}^{-1}$ in early exponential growth phase-close to the 'ideal' rate of $1.0 \mathrm{div} . \mathrm{d}^{-1}$. Attempts to enhance synchrony in C. polylepis by exposure to prolonged darkness ( 2 to $3 \mathrm{~d}=2$ to 3 cell division cycles) yielded cultures exhibiting long lagphases, and sometimes the cultures never recovered at all (U. John et al. unpubl. data).

Synchronous growth was indicated by the stepwise increase in cell numbers and chl a content following the well-known scheme for photosynthetic flagellates of cell division during the dark period and chl a synthesis during the light period (Fig. 2A). This pattern has also been shown in the dinoflagellate studies of Taroncher-Oldenburg et al. (1997) and Pan et al. (1999). Growth rates showed a successive decrease from 0.82 (Day 3.5) to 0.65 (Day 4.5) and finally to 0.61 div. $d^{-1}$ (Day 5.5) Fig. 3 indicates that the cultures entered the transition from late exponential to early stationary phase by this time.

Unbalanced growth is one effect of batch cultures, whereby high metabolic needs cannot be compensated by nutrient uptake over extended periods of time because of the exceeding high growth rates of the cells and progressively increasing biomass. The maximum growth rate $\left(\mu_{\max }\right)$ for each strain/species is limited by intrinsic factors such as the maximal rate of synthesis of bioenergetic metabolites, DNA and proteins. Below this threshold, growth rates are limited by external factors, such as rate-limiting supply of nutrients, irradiance or diffusion of $\mathrm{CO}_{2}$. Continuous aeration of our cultures mitigated the effects of carbon limitation and, to some degree, $\mathrm{pH}$ changes. It is unlikely that the nutrients in the medium used in our cultures were exhausted during our short experimental time, since IMR $1 / 2$ is a highly nutrient-enriched medium. In this regard, Schmidt \& Hansen (2001) calculated that their batch cultures of Chrysochromulina polylepis, grown on comparable $f / 2$ medium used approximately 10 to $20 \%$ of available nutrients in their medium by the end of a 2 to $3 \mathrm{wk}$ time course. In our experiments, the cultures were harvested much earlier (on Days 3 and 6), suggesting that macronutrient (including carbon) limitation did not play a role in decreasing growth rates.

In this study, the incident photon flux density was rather low $\left(45 \mu \mathrm{mol}\right.$ photons $\left.\mathrm{m}^{-2} \mathrm{~s}^{-1}\right)$, but this selection of light intensity was shown in preliminary experiments with this strain to sustain maximal growth rate. Nevertheless, it is possible that the cultures may have become light-limited as cell concentration increased. Increasing cell concentration in batch cultures can influence growth rate as well as synchronisation efficiency through a variety of mechanisms including a rise in 'self-shading' from the increasing biomass. For example Lemaire et al. (1999) observed that in Chlamydomonas reinhardii cultures, higher synchronisation efficiency in more dilute cultures could be attributed to better homogeneity of the culture, and hence a better light quality and quantity received by 
each cell. Lower light quality and quantity and reduced cell size reduce the number of cells which can potentially complete the cell cycle and hence reduce synchronisation efficiency. However, in our experiment the synchronisation efficiency actually increased with increasing cell concentration.

\section{Cell-cycle analysis}

The cell cycle of Chrysochromulina polylepis has been previously analysed by flow cytometry (Edvardsen \& Vaulot 1996). In our experiments, cell-cycle analysis was accomplished by quantifying the amount of DNA in fixed cells (Grey et al. 1990), but we used an improved method based on glutaraldehyde fixation (Eschbach et al. 2001a). At the beginning of our experiments, C. polylepis cultures were in quasi-steady state (roughly balanced growth) and the cells passed through $\mathrm{S}$ and $\mathrm{G} 2+\mathrm{M}$ phases during the dark period (Fig. 2C). Mitotic division in the dark is typical for many other microalgae, although there are exceptions to this rule, particularly for shade-adapted benthic species (Pan \& Cembella 1998). During the light period, all C. polylepis cells accumulated in the G1 phase, during which growth and other metabolic functions, such as chlorophyll and toxin biosynthesis, were carried out.

After the second round of cell division, there appeared to be a slight temporal shift of the cell-cycle phases during the dark period. The second complete cell cycle lasted $3 \mathrm{~h}$ longer than the first cycle. Careful examination of the individual phases of the cell cycle indicated a progressive increase in the length of the G1 phase. Other reports support the finding that lengthening of the generation time accompanies decreasing growth rates and is attributable to expansion of a single cell-cycle phase, namely the G1 phase (Olson \& Chisholm 1986, Micheli et al. 1996). As previously noted, for species grown phototrophically, such as the Chrysochromulina polylepis cultures in the current experiments, light is of primary importance for activating physiological processes and regulating progression through cell-cycle events. The observed elongation of the G1 phase is consistent with the observation of Olson \& Chisholm (1986) (and references therein) that light and nutrient limitation primarily influence processes in the G1 phase, resulting in prolongation and a decrease in cell size. Light- and cell size-dependent transition points have also been documented in a variety of photoautrophic microalgae, including Amphidinium carteri (Olson \& Chisholm 1986), Hymenomonas carterii and Thalassiosira weisflogii (Vaulot et al. 1986), and Alexandrium fundyense (Taroncher-Oldenburg et al. 1997). Cells that have passed the transition point will complete the cell cycle regardless of external conditions. Whether they pass this point depends on, for instance, light intensity and day length or cell size; if the cells do not pass the transition point they stay arrested in the G1 or G0 phases.

\section{Toxin biosynthesis}

In previous studies on the relationship of toxin synthesis to cell cycle phases in marine dinoflagellates, toxin production was found to be restricted to a defined period of the cell cycle. In the planktonic dinoflagellate Alexandrium fundyense, a causative organism responsible for paralytic shellfish poisoning, saxitoxin analogues were produced during a $10 \mathrm{~h}$ period within the G1 phase, with slight time shifts in the synthesis of different derivatives (Taroncher-Oldenburg et al. 1997). Nevertheless, there were some important differences in the phasing of toxin production among dinoflagellates: in $A$. fundyense, biosynthesis of the tetrahydropurine neurotoxins was restricted to the G1 phase, whereas this was not strictly true for the polyketide-derived toxins of $A$. ostenfeldii (spirolides) (John et al. 2001) and Prorocentrum lima (okadaic acid derivatives; dinophysistoxins, DTX) (Pan et al. 1999). For the shade-adapted benthic dinoflagellate $P$. lima (a cause of diarrhetic shellfish poisoning), the DTX derivatives produced during the beginning of the light period ('morning') in the G1 phase were different than those synthesised later in the photocycle ('afternoon') during the S and G2 phases (Pan et al. 1999). In all cases, toxin biosynthesis in these dinoflagellates is not continuous, but follows a strict time schedule coupled to their cell cycle, and is light-dependent.

In Chrysochromulina polylepis, under non-limiting nutrient conditions, toxicity is highest in the midexponential growth phase, whereas in phosphoruslimited cultures, cells remain highly toxic in the stationary phase (Edvardsen et al. 1996). However, the effects of nutrient limitation must be carefully interpreted because such limitation can lead to toxin accumulation in cells merely by reduced cell division. Hence, an increase in toxin cell quota does not necessarily result from an increase in the rate of toxin production (Taroncher-Oldenburg et al. 1997, Cembella 1998, John et al. 2001). Nevertheless, the fact that highest cell toxicity in C. polylepis was recorded during the exponential growth phase indicates that the rate of toxin synthesis is highest when the growth rate is maximal (Edvardsen et al. 1996).

Quantitative and qualitative analysis of the toxins produced by Chrysochromulina polylepis is hampered by the fact that these ichthyotoxic substances are chemically poorly described. Without certainty of the 
chemical structures of these toxins, it is not possible to employ chemical analytical techniques, e.g. liquid chromatography with fluorescence or mass detection, in studies of toxin expression through the cell cycle. Nevertheless, because these toxins are known to cause lysis of cells, the mechanism that damages the gills of fishes (Skjoldal \& Dundas 1991), the ELA can be employed to estimate potential toxic activity. The assay has recently been improved for more sensitivity and high sample throughput (Eschbach et al. 2001b) and can be used as a proxy for ichthyotoxicity estimates.

Simonsen \& Moestrup (1997) showed haemolytic capacity for 8 different Chrysochromulina species, but only C. polylepis was toxic to Artemia sp. In our experiments, cell extracts of Clones B1511 and B11 of C. polylepis expressed different haemolytic effects (Fig. 4), and therefore the differences in haemolytic capacity of the 2 clones are assumed to be related to the toxicity.

In the work of Yasumoto et al. (1990), the haemolytic capacity and the ichthytoxicity of Chrysochromulina polylepis were mainly attributed to galactolipids, 1acyl-3-digalacto-glycerol and polyunsaturated fatty acids (PUFAs). However, John et al. (2002) demonstrated that Clone B11, which showed no toxicity towards Artemia sp. larvae, and Clone B1511, which was highly toxic towards these crustaceans, exhibited no difference in lipid and PUFA composition. This led to the conclusion that the difference in toxicity may be explained by substances other than lipids or PUFAs.

As has been reported for dinoflagellates (TaroncherOldenburg et al. 1997, Pan et al. 1999), toxicity (as lytic activity) of Chrysochromulina polylepis also appears to be induced by light and is discontinuous over the cell cycle. The $\mathrm{LC}_{50}$ increases as the haemolytic activity drops during the middle of the dark period and decreases at the end of the dark period until the first few hours of the light period, leading to an intracellular accumulation of the toxin(s) (Fig. 2E). The dramatic decrease in toxicity per cell (expressed as increased $\mathrm{LC}_{50}$ ) corresponds to cell-division events and the increase in toxicity with the start of light period and early G1 phase when the daughter cells produce the toxic/ haemolytic compounds. However, this rhythmic behaviour for the lytic activity lasted only for the first $48 \mathrm{~h}$ of the sampling period; thereafter, lytic activity of the cells showed large variation, resulting in a less rhythmic course of the haemolytic activity curve (Fig. 2E). The induction of toxicity was not pronounced in the third light:dark cycle, although synchronisation efficiency was even higher than in the 2 earlier light:dark cycles, leading to the suggestion that light is one of the major factors regulating toxin production and confirming earlier findings that toxicity decreases in the early stationary phase. This observation is also consistent with the results of Pan et al. (1999), who found that toxin production in Prorocentrum lima was simultaneously initiated when the dark-arrested cells were released to the regular light:dark cycle. However, with our experiments we cannot distinguish if toxicity is light- or G1-dependent. This question should be answered in future experiments, which should take circadian regulation into account.

In conclusion, Chrysochromulina polylepis proceeds through a typical eukaryotic cell cycle with a distinct DNA synthesis phase. Toxin production in C. polylepis (and presumably other haptophytes growing photoautotrophically) can be studied with synchronised cultures in a manner similar to that for dinoflagellates (Taroncher-Oldenburg et al. 1997, Pan et al. 1999). Moreover, the analysis of toxin biosynthesis and its regulation at the gene and protein levels must be advanced in order to understand the mechanisms of toxin induction under different environmental conditions. Now that we have demonstrated that toxin biosynthesis (or at least expressed toxicity) in C. polylepis is switched on within a narrow time window at the beginning of the G1 phase of the cell cycle, it is possible to pursue directed molecular biological approaches to understand these phenomena.

Acknowledgements. This research was supported as part of the BMBF TEPS project 03F0244. We thank M. Henschke (Technical University, Aachen, Germany) for helping with the calculation of synchronisation efficiency and cell-cycle phase durations.

\section{LITERATURE CITED}

Arar EJ, Collins GB (1992) In vitro determination of chlorophyll $a$ and phaeophytin $a$ in marine and freshwater phytoplankton by fluorescence. Method 445.0. In: Methods for the determination of chemical substances in marine and estuarine environmental samples. US Environmental Protection Agency, Cincinnati, $\mathrm{OH}$

Beck HP (1978) A new analytical method for determining duration of phases, rate of DNA synthesis and degree of synchronization from flow-cytometric data on synchronised cell populations. Cell Tissue Kinetic 11:139-148

Carré IA, Edmunds LN (1993) Oscillator control of cell division in Euglena: cyclic AMP oscillation mediate the phasing of the cell division cycle by the circadian clock. J Cell Sci 104:1163-1173

Cembella AD (1998) Ecophysiology and metabolism of paralytic shellfish toxins in marine microalgae. In: Anderson DM, Cembella AD, Hallegraeff GM (eds) Physiological ecology of harmful algal blooms. Springer-Verlag, Berlin, p 381-403

Chisholm SW (1981) Temporal patterns of cell division in unicellular algae. Can Bull Fish Aquat Sci 210:150-181

Chisholm SW, Vaulot D, Olson RJ (1984) Cell cycle controls in phytoplankton: comparative physiology and ecology. In: Edmunds LN (ed) Cell cycle clocks. Marcel Dekker, New York, p 365-394 
Dahl E, Lindahl O, Paasche E, Throndsen J (1989) The Chrysochromulina polylepis bloom in Scandinavian waters during spring 1988. In: Cosper EM, Bricelj M, Carpenter EJ (eds) Novel phytoplankton blooms: causes and impacts of recurrent brown tides and other unusual blooms. Springer-Verlag, Berlin, p 383-405

Edvardsen B (1993) Toxicity of Chrysochromulina species (Prymnesiophyceae) to the brine shrimp, Artemia salina. In: Smayda TJ, Shimizu Y (eds) Toxic phytoplankton blooms in the sea. Elsevier, Amsterdam, p 681-686

Edvardsen B, Paasche E (1992) Two motile stages of Chrysochromulina polylepis (Prymnesiophyceae): morphology, growth and toxicity. J Phycol 28:104-114

Edvardsen B, Paasche E (1998) Bloom dynamics and physiology of Prymnesium and Chrysochromulina. In: Anderson DM, Cembella AD, Hallegraeff GM (eds) Physiological ecology of harmful algal blooms. Springer-Verlag, Berlin, p 193-208

Edvardsen B, Vaulot D (1996) Ploidy analysis of the 2 motile forms of Chrysochromulina polylepis (Prymnesiophyceae). J Phycol 32:94-102

Edvardsen B, Moy F, Paasche E (1990) Hemolytic activity in extracts of Chrysochromulina polylepis grown at different levels of selenite and phosphate. In: Granéli E, Sundström B, Edler L, Anderson DM (eds) Toxic marine phytoplankton. Elsevier, New York, p 284-289

Edvardsen B, Larsen A, Kristiansen S, Paasche E (1996) The effect of growth stage, salinity, temperature and nutrient limitation on the toxicity of Chrysochromulina polylepis (Prymnesiophyceae). In: Toxicity, autecology and life history of Chrysochromulina polylepis (Haptophyta). PhD thesis, Publ VI, University of Oslo, Oslo

Engelberg J (1961) A method of measuring the degree of synchronization of cell populations. Exp Cell Res 23:218-227

Eppley RW, Holmes RW, Strickland JDH (1967) Sinking rates of marine phytoplankton measured with a fluorometer. J Exp Mar Biol Ecol 1:191-208

Eschbach E, Reckermann M, John U, Medlin LK (2001a) A simple and highly efficient fixation method for Chrysochromulina polylepis (Prymnesiophytes) for analytical flow cytometry. Cytometry 44:126-132

Eschbach E, Scharsack JP, John U, Medlin LK (2001b) Improved erythrocyte lysis assay in microtitre plates for sensitive detection and efficient measurement of haemolytic compounds from ichthyotoxic algae. J Appl Toxicol 21: 513-519

Gerath MW, Chisholm SW (1989) Change in photosynthetic capacity over the cell cycle in light/dark-synchronized Amphidinium carteri is due solely to the photocycle. Plant Physiol 91:999-1005

Gjøsæter J, Lekve K, Stenseth NC, Leinaas HP and 7 others (2000) A long-term perspective on the Chrysochromulina bloom on the Norwegian Skagerrak coast 1988: a catastrophe or an innocent incident? Mar Ecol Prog Ser 207: 201-218

Granéli E, Paasche E, Maestrini SY (1993) Three years after the Chrysochromulina polylepis bloom in Scandinavian waters in 1988: some conclusions of recent research and monitoring. In: Smayda TJ, Shimizu Y (eds) Toxic phytoplankton blooms in the sea. Elsevier, Amsterdam, p 23-32

Grey JW, Dolbeare F, Pallavicini MG (1990) Quantitative cell cycle analysis. In: Melamed MR, Lindmo TL, Mendelsohn ML (eds) Flow cytometry and sorting, 2nd edn. Wiley-Liss, New York, p 445-467

Hallegraef GM (1993) A review of harmful algae blooms and their apparent global increase. Phycologia 32:79-99

Jacobsen A (2002) Morphology, relative DNA content and hypothetical life cycle of Phaeocystis pouchetii (Prymnesiophyceae), with special emphasis on the flagellated cell type. Sarsia 87:338-349

Jebram D (1980) Prospection for a sufficient nutrition for the cosmopolitic marine bryozoan Electra pilosa (Linnaeus). Zool J Syst Evol Res 107:368-390

Johansson N, Granéli E (1999) Cell density, chemical composition and toxicity of Chrysochromulina polylepis (Haptophyta) in relation to different N:P supply ratios. Mar Biol 135:209-217

John U, Quilliam MA, Medlin L, Cembella AD (2001) Spirolide production and photoperiod-dependent growth of the marine dinoflagellate Alexandrium ostenfeldii. In: Hallegraeff GM, Blackburn SI, Bolch CJ, Lewis RJ (eds) Harmful algal blooms 2000. Intergovermental Oceanographic Commission (UNESCO), Paris, p 299-302

John U, Tillmann U, Medlin LK (2002) A comparative approach to study grazer interference and lipid composition of a toxic and non-toxic clone of Chrysochromulina polylepis (Prymnesiophyceae). Harmful Algae 1:45-57

Johnsen G, Dallökken R, Eikrem W, Legrand C, Aure J, Skjoldal HR (1999) Eco-physiology, bio-optics and toxicity of the ichthyotoxic Chrysochromulina leadbeateri (Prymnesiophyceae). J Phycol 35:1465-1476

Larsen A. Edvardsen B (1998) A study of relative ploidy levels in Prymnesium parvum and P. patelliferum (Haptophyta) analysed by flow cytometry. Phycologia 37:412-424

Lemaire SD, Hours M, Gerard-Hirne C, Trouabal A, Roche O, Jacquot JP (1999) Analysis of light/dark synchronization of cell-wall-less Chlamydomonas reinhardii (Chlorophyta) cells by flow cytometry. Eur J Phycol 34:279-286

MacIntryre JG, Cullen JJ, Cembella AD (1997) Vertical migration, nutrition and toxicity in the dinoflagellate Alexandrium tamarense. Mar Ecol Prog Ser 148:201-216

Manton I, Parke M (1962) Preliminary observations on scales and their mode of origin in Chrysochromulina polylepis sp. nov. J Mar Biol Assoc UK 42:565-578

Micheli C, Magaletti E, Chimenz C (1996) Effect of stress on the growth and cell cycle of dinoflagellates. In: Yasumoto T, Oshima Y, Fukuyo Y (eds) Harmful and toxic algal blooms. Sendai Kyodo Printing, Sendai, p 317-319

Ng CKF, Lam CMC, Yeung PKK, Wong JTY (1999) Flow cytometric analysis of nocodazole-induced cell-cycle arrest in the pennate diatom Phaeodactylum tricornutum Bohlin. J Appl Phycol 10:569-572

Nielsen TG, Kiørboe T, Bjørnsen PK (1990) Effects of a Chrysochromulina polylepis subsurface bloom on the planktonic community. Mar Ecol Prog Ser 62:21-35

Ober K (1975) Effects of diazepam on photosynthesis, respiration, rubidium uptake, and fine structure of Scenedesmus obliquus in synchronous cultures. Arch Microbiol 102: 129-137

Olson RJ, Chisholm SW (1986) Effects of light and nitrogen limitation on the cell cycle of the dinoflagellate Amphidinium carteri. J Plankton Res 8:785-793

Paasche E, Edvardsen B, Eikrem W (1990) A possible alternate stage in the life cycle of Chrysochromulina polylepis Manton et Parke (Prymnesiophyceae). Nova Hedwigia (Beih) 100:91-99

Pan Y, Cembella AD (1998) Flow cytometric determination of cell cycles and growth rates of Prorocentrum spp. In: Reguera B, Blanco J, Fernández ML, Wyatt T (eds) Harmful algae. Yunta de Galicia and Intergovernmental Oceanographic Commission (UNESCO), p 173-176

Pan Y, Cembella AD, Quilliam MA (1999) Cell cycle and toxin production in the benthic dinoflagellate Prorocentrum lima. Mar Biol 134:541-549 
Pardee AB, Dubron R, Hamlin JL, Klevtzien RF (1978) Animal cell cycle. Annu Rev Biochem 47:715-750

Rizzo PJ (1987) Biochemistry of the dinoflagellate nucleus. In: Taylor FJR (ed) The biology of dinoflagellates. Blackwell Scientific, London, p 143-173

Rosenberg R, Lindahl O, Blanck H (1988) Silent spring in the sea. Ambio 17:289-290

Schmidt LE, Hansen PJ (2001) Allelopathy in the prymnesiophyte Chrysochromulina polylepis: effect of cell concentration, growth phase and pH. Mar Ecol Prog Ser 216: $67-81$

Simonsen S, Moestrup O (1997) Toxicity tests in eight species of Chrysochromulina (Haptophyta). Can J Bot 75:129-136

Skjoldal HR, Dundas I (1991) The Chrysochromulina polylepis bloom in the Skagerrak and the Kattegat in MayJune 1988: environmental conditions, possible causes and effects. Int Counc Explor Sea Coop Res Rep 175:59

Tangen K (1989) Algal blooms in Norway in 1989. Red Tide Newsl 2:2-3

Tangen K, Brieby A (1988) A new outbreak of Chrysochromulina polylepis. Red Tide Newsl 1:4-5

Taroncher-Oldenburg G, Kulis DM, Anderson DM (1997) Toxin variability during the cell cycle of the dinoflagellate Alexandrium fundyense. Limnol Oceanogr 42:1178-1188

Throndsen J, Larsen J, Moestrup O (1995) Toxic algae: toxicity of Chrysochromulina with new ultrastructural information on C. polylepis. In: Wiessner W, Schnepf E, Starr RC

Editorial responsibility: William Li, Dartmouth, Nova Scotia, Canada (eds) Algae, environment and human affairs. Biopress, Bristol, p 201-222

van Dolah FM, Leighfield TA, Sugg LM (1998) Mechanisms regulating the cell cycle in two dinoflagellate species, Gambierdiscus toxicus and Amphidinium operculatum. In: Reguera B, Blanco J, Fernández M, Wyatt T (eds) Harmful algae. Yunta de Galicia and Intergovernmental Oceanographic Commission (UNESCO), p 156-159

Vaulot D, Olson RJ, Chisholm SW (1986) Light and dark control of the cell cycles in two marine phytoplankton species. Exp Cell Res 167:38-52

Vaulot D, Birrien JL, Marie D, Casotti R, Veldhuis MJW, Kraay GW, Chrétiennot-Dinet MJ (1994) Morphology, ploidy, pigment composition, and genome size of cultured strains of Phaeocystis (Prymnesiophyceae). J Phycol 30: 1022-1035

Wanka F, Moors J, Krijzer FNCM (1972) Dissociation of nuclear DNA replication from concominant protein synthesis in synchronous cultures of Chlorella. Biochim Biophys Acta 269:153-161

Yasumoto T, Underdal B, Aune T, Hormazabal V, Skulberg OM, Oshima Y (1990) Screening for hemolytic and ichthyotoxic components of Chrysochromulina polylepis and Gyrodinium aureolum from Norwegian coastal waters. In: Granéli E, Sundström B, Edler L, Anderson DM (eds) Toxic marine phytoplankton. Elsevier, New York, p 436-440

Submitted: April 7, 2004; Accepted: January 7, 2005 Proofs received from author(s): April 12, 2005 